\title{
Potential Carcinolytic Agents. VI. New Deactivated Biological Alkylating Agents ${ }^{1}$
}

In our studies of deactivated alkylating agents ${ }^{2}$, i.e. agents whose alkylating power has been subdued by rendering the nitrogen atom more electropositive, we have prepared some quaternary ammonium mustards I which are active against a number of experimental rodent tumors.

The chemical mechanism by which the nitrogen mustards, bis(2-chloroethyl)amines, effect alkylation in vitro is well understood ${ }^{3}$ and has led to theories concerning the in vivo action of these agents ${ }^{4}$. It is generally accepted that the mechanism involves the formation of the very reactive cyclic ethylenimmonium ion ${ }^{\mathbf{s}}$, which, of course, would be impossible in quaternary ammonium mustards. The compounds prepared in the present study were designed to split under certain conditions in vitro ${ }^{B}$ and possibly in vivo (e.g. attack by a nucleophile such as mercaptide), releasing the active nitrogen mustard moiety according to the following equation.

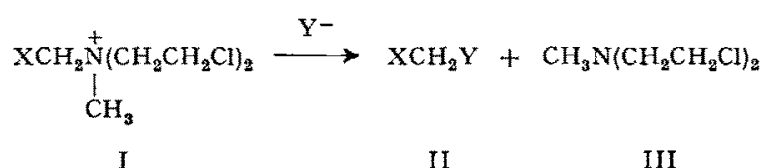

The oxazolinium salt IV is the only example ${ }^{7}$ of a quaternary nitrogen mustard found active against Yoshida Sarcoma. The authors postulated that IV is activated in vivo by reduction as in bis (2-chloroethyl). methylamine oxide. On the other hand, the bioisostere? $V$ and compounds of the general structure ${ }^{8}$ VI were found inactive against Yoshida Sarcoma and Ehrlich's ascites carcinoma respectively.

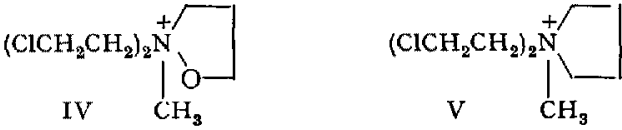

$$
\begin{aligned}
& \left(\mathrm{ClCH}_{2} \mathrm{CH}_{2}\right)_{2} \stackrel{+}{\stackrel{+}{\mathrm{N}}}-\mathrm{CH}_{2} \mathrm{OR}
\end{aligned}
$$

Preliminary screening showed that Ia $\left(\mathrm{X}=p-\mathrm{NO}_{2} \mathrm{C}_{6} \mathrm{H}_{4}-\right)$ was active against $\mathrm{DA}^{10}$ in the range of $0.08-2.5 \mathrm{mg} / \mathrm{kg}$ (T.I. $\left.{ }^{11}>30\right)$. It was also active against $\mathrm{WA}^{13}$ in the range of $1-4 \mathrm{mg} / \mathrm{kg}$ (T.I. ${ }^{11}>4$ ), and against WM ${ }^{12}$ in the range of $3.5-24 \mathrm{mg} / \mathrm{kg}$ (T.I. ${ }^{11}>7$ ). On the other hand, the unsubstituted compound $\mathrm{Ib}\left(\mathrm{X}=\mathrm{C}_{6} \mathrm{H}_{5}\right)$ and the orthosubstituted compounds Ic $\left(\mathrm{X}=0-\mathrm{NO}_{2} \mathrm{C}_{6} \mathrm{H}_{4}-\right)$ and Id $\left(\mathrm{X}=0-\mathrm{CH}_{3} \mathrm{OOCC}_{6} \mathrm{H}_{4}-\right.$ ) displayed only moderate activity. Against $\mathrm{DA}^{10}, \mathrm{Ib}$ was active at $20-40 \mathrm{mg} / \mathrm{kg}$ (T.I. ${ }^{11} \mathrm{ca} .2$ ) and $\mathrm{Ic}$ was active at $1.25-2.5 \mathrm{mg} / \mathrm{kg}\left(T . I^{11} \simeq 2\right.$ ). Id was active at $10-20 \mathrm{mg} / \mathrm{kg}\left(\mathrm{T} . \mathrm{I}^{11} \simeq 2\right)$ in $\mathrm{WA}^{13}$.

These results indicate that the quaternary mustards are active against experimental tumors sensitive to biological alkylating agents. (At the same time, Ib, for instance, was inactive in Dunning Leukemia resistant to cyclophosphamide, an alkylating agent.) The fact that electron-withdrawing substituents that do not provide steric hindrance to nucleophilic attack at the benzylic carbon increase the activity of the quaternary mustards seems to support our proposed activation scheme.

In another series of compounds, Ie ( $\mathrm{X}=\mathrm{C}_{2} \mathrm{H}_{5} \mathrm{OOC}-$ was found to prolong the survival of mice implanted with $\mathrm{LE}^{14}, \mathrm{~T} / \mathrm{C}^{15} 172 \%$, at $30-50 \mathrm{mg} / \mathrm{kg}$, and to cure $\mathrm{WA}^{13}$ at $10-40 \mathrm{mg} / \mathrm{kg}\left(\mathrm{T} . \mathrm{I}^{11} \simeq 4\right)$; If $\left(\mathrm{X}=\mathrm{C}_{2} \mathrm{H}_{5} \mathrm{OOCCH}_{2} \mathrm{NHOC}-\right)$ was active in $\mathrm{DA}^{10}$ at $4-64 \mathrm{mg} / \mathrm{kg}\left(T . I .{ }^{11} \simeq 16\right)$, but inactive in cyclophosphamide-resistant Dunning Leukemia.
The quaternary ammonium mustards I were prepared by reaction of an ethereal solution of methyl-bis(2-chloroethyl)amine III with the corresponding bromide II ( $\mathrm{Y}=\mathrm{Br}$ ). The products which crystallized from the reaction mixture gave correct analyses.

The ideas and results outlined above, in addition to providing leads for preparing new biological alkylating agents, might be extended into other areas of medicinal chemistry where quaternization of a tertiary amine with a suitable leaving group could impart water solubility to a water-insoluble, biologically active agent (drug, pesticide, insecticide, etc.) and alter the absorption, distribution, and activity of the agent ${ }^{16}$.

Résumé. Les auteurs ont effectué de nouvelles préparations chimiques anticancéreuses en utilisant une forme des agents alkylants déactivés du type moutarde nitrogénée quaternaire. Un mode d'action est proposé par lequel ces préparations peuvent être activées in vivo.

Z. B. Papanastassiou,

R. J. BRUNi and E. White, V

Arthur D. Little, Inc., Cambridge

(Massachusetts 02140, USA), 4 December 1967.

1 Sponsored by the Cancer Chemotherapy National Service Center, National Cancer Institute, National Institutes of Health, Contract No. SA-43-ph-4360.

2. B. Papanastassiov, R. J. Bruni and E. White, J. med. Chem. 10, 701 (1967).

3 P. L. Levins and Z, B. Papanastassiou, J. Am. chem. Soc. 87 $826(1965)$ and references cited therein.

4 P. D. LAwley and P. Brooks, Biochem. J. 89, 127 (1963).

* W. C. J. Ross, Biological Alkylating Agents (Butterworth and Co. (Publishers) Ltd., London 1962).

- J. GOERDELER in Methodender Organischen Chemie (Ed. E. MULLER; Georg Thieme Verlag, Stuttgart 1958), vol. 11/2, p. 633 .

7 M. Ishidate, Y. Sakural and M. Torigoe, Chem. pharm. Bull,, Tokyo 9, 485 (1961). - M. Torigor, Chem. pharm. Bull., Tokyo 9,613 (1961).

M. Wunderwald and W. Ozegowski, J. prakt. Chem. 19, 238 (1963).

- The compounds were screened by the Cancer Chemotherapy National Service Center. For protocols for screening against animal tumors, see Cancer Chemother. Rep. 25, 1 (1962), and for comparison with other known drugs, see L. H. Schmidt, R Fradkin, R. Sullivan and A. Flowers, Cancer Chemother. Rep. Suppl. 2, 1 (1965).

10 Dunning leukemia (ascites) in Fischer 344 rats. Five daily i.p. injections starting $I$ day after tumor implantation. Animals sacrificed on the thirtieth day.

11 Therapeutic index is maximum tolerated dose $\left(\mathrm{LD}_{50}\right.$ in $\left.\mathrm{mg} / \mathrm{kg}\right)$ per minimum effective dose ( $\mathrm{T} / \mathrm{C} 0.10$ in $\mathrm{mg} / \mathrm{kg}$ ).

12 Walker carcinosarcoma 256 (i.m.) in random bred albino rats. Four i.p. injections starting 3 days after tumor implantation. Animals sacrificed on the seventh day and tumors weighed.

13 Walker carcinosarcoma 256 (s,c) in random bred albino rats. Five i.p, injections starting 1 day after tumor implantation. Animals sacrificed on the tenth day and tumors weighed.

14 Lymphoid leukemia $\mathrm{L}-1210$ in $\mathrm{BDF}_{1}$ mice. Fifteen daily i.p. injections starting 1 day after tumor implantation.

15 Ratio of survival time of treated animals to that of control animals.

18 Acknowledgment. We thank Dr. W. M. WhaLEY for his contributions and encouragement in the initial phases of our program. 